\title{
Spatiotemporal variation of the ozone QBO in MLS data by wavelet analysis
}

\author{
S. Fadnavis and G. Beig \\ Indian Institute of Tropical Meteorology, Dr. Homi Bhabha Road, PashanPune, 411008, India \\ Received: 30 April 2008 - Revised: 10 October 2008 - Accepted: 17 October 2008 - Published: 25 November 2008
}

\begin{abstract}
Spatiotemporal characteristics of the ozone quasibiennial oscillation (QBO) over the tropical-subtropical stratosphere $\left(40^{\circ} \mathrm{S}-40^{\circ} \mathrm{N}\right)$ have been examined by analyzing data from the Microwave Limb Sounder (MLS) aboard Upper Atmospheric Research Satellite (UARS) for the period 1992-1999. A combination of regression analysis and wavelet analysis combines to act as an accurate QBO filter. Wavelet analysis provides inter-annual variability of amplitude and phase of the ozone QBO in the vertical structure of tropical-subtropical stratosphere. It gives minute details of phase propagation and descend rates, which can be used as input to models. Latitude-height structure shows evidence of a secondary meridional circulation induced by the QBO as double peak structure at the equator with maximum amplitude at two pressure levels $30 \mathrm{hPa}$ and $9 \mathrm{hPa}$ and a node at $14 \mathrm{hPa}$. The equatorial maxima are out of phase with each other. The maximum amplitude $(\sim 1.4 \mathrm{ppmv})$ of the ozone QBO was observed near the equator at $10 \mathrm{hPa}$. Descent rate of the easterly phase is greater than westerly. The lag correlation of the ozone QBO with circulation and variation of descent rates in the vertical structure of the stratosphere are examined in detail. In the equatorial upper stratosphere ozone anomalies descent with the rate $\sim 1.5 \mathrm{~km} /$ month but in tropics and subtropics (above $2 \mathrm{hPa}$ ) they propagate upward.
\end{abstract}

Keywords. Atmospheric composition and structure (Middle atmosphere - composition and chemistry) - Meteorology and atmospheric dynamics (Middle atmosphere dynamics; Waves and tides)

\section{Introduction}

A Quasi Biennial Oscillation (QBO) in equatorial zonal wind is a dominant characteristic of the lower stratosphere. The

Correspondence to: S. Fadnavis

(suvarna@ tropmet.res.in)
QBO was discovered by Reed et al. (1961). Subsequent observational (Soukharev, 1997; Kondratiyev, 1990; Stolarski et al. 1991; Chandra and McPeters 1994) as well as numerical simulations (Mayr et al., 2003; Lee and Smith, 2003; McCormack, 2003; Yuejuan et al., 2005; Cordero and Nathan, 2005) have reported various features of the QBO. The influence of the QBO on many trace gases including methane, water vapor, ozone, $\mathrm{NO}_{2}, \mathrm{HCl}$, volcanic aerosol have been reported in the past (Dunkerton, 2001; Jones et al., 1998; Fleming et al., 2002; Yuejuan et al., 2005; Fadnavis et al., 2007).

A QBO in total ozone amount over the tropics was first reported by Funk and Garnham (1962) and Ramanathan (1963). Regression analysis applied on SAGE II ozone measurements showed that the QBO dominates ozone variability at the equator with alternate positive and negative anomalies which propagate downward with time (Zawodny and McCormick, 1991; Randel and Wu, 2007, 1996). There are two regions of maximum ozone perturbation - near $20-27 \mathrm{~km}$ and near $30-37 \mathrm{~km}$. The anomalies at these levels are out of phase and indicate a node at $28 \mathrm{~km}$. From model simulations Chipperfield et al. (1994) and Jones et al. (1998) reported similar double peak structure (with two maxima of about $4 \%$ centered at about 24 and $32 \mathrm{~km}$ ). Using HALOE data from 1992 to 2000 and numerical simulation, Yuejuan et al. (2002) reported that in the tropical region, the phase of the ozone QBO changes many times with increase in height. Numerical simulation shows that the meridional circulation induced by the zonal wind QBO includes three pairs of cells in the stratosphere which have hemispheric symmetry. Li et al. (1997) found that the QBO (for circulation) in the Northern Hemisphere is generally stronger than in the Southern Hemisphere. From SBUV ozone for the period 1979-2003 and model simulations McCormack et al. (2007) reported solar-QBO interaction on stratospheric ozone. The QBO signal in the subtropics shows a phase reversal near $15^{\circ}$ with hemispheric asymmetry (Yang and Tung, 1995; Baldwin et

Published by Copernicus Publications on behalf of the European Geosciences Union. 

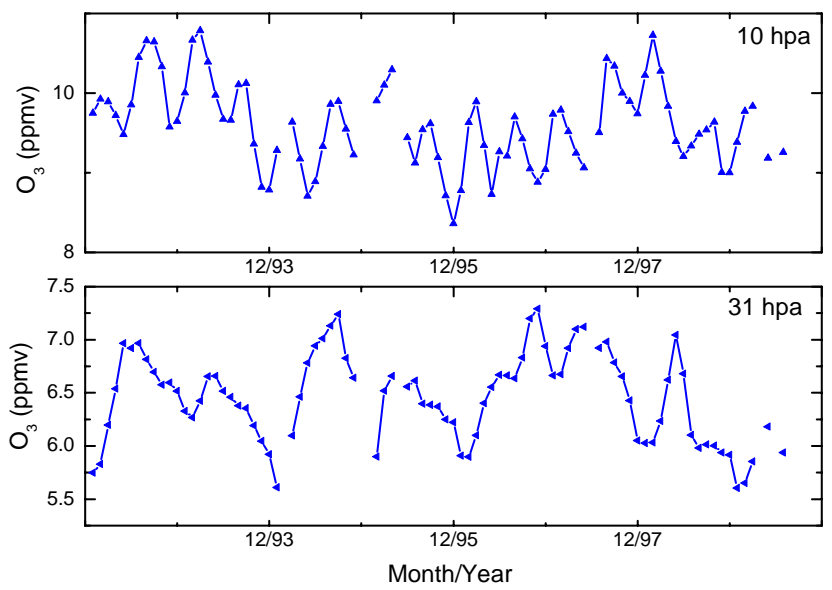

Fig. 1. Time series of zonal mean ozone volume mixing ratio over 0-10 $\mathrm{N}$ latitudinal band for the period January 1992-July 1999 at two representative pressure levels $(10 \mathrm{hPa}$ and $31 \mathrm{hPa})$.

al., 2001). A comprehensive review of all aspects of the QBO and its effects on trace species has been documented by Baldwin et al. (2001).

During the last several decades, satellite data have provided profiles of ozone volume mixing ratio. Studies using HALOE data (Yuejuan et al., 2002; Dunkerton, 2001) and SAGE II data (Zawodny and McCormick, 1991; Randel and $\mathrm{Wu}, 1996)$ have characterized the vertical structure of the ozone QBO. Most studies detect the QBO using Fourier transform, spectral, or regression analysis (Ray and Holton 1994; Zawodny and McCormick, 1991; Randel and Wu, 1996), which do not provide information about the time evolution of amplitude and phase of QBO. Regression analysis uses QBO proxy indices (Singapore zonal winds) to identify the QBO signal. These proxy indices may modulate amplitude and phase of the QBO. The main disadvantage of this method is that although Singapore zonal winds are measured at $1^{\circ} \mathrm{N}$ they are used to compute the QBO signal over low, mid and high latitudes. Wavelet analysis uses Windowed Fourier Transform (WFT) with varying width window. Hence it can capture localized variations of power within a time series. Wavelet analysis gives time evaluation of amplitude and phase of the QBO. It is the best tool to obtain downward propagating of alternately varying easterly and westerly phase of the QBO. Hence, it is a powerful tool, using which decent rates can be estimated accurately in the vertical structure of the stratosphere. It has been used for numerous studies in geophysics (Wang and Wang, 1996; Baliunas et al., 1997).

In this study we have used a combination of regression analysis and wavelet analysis to detect an accurate QBO signal. The spatiotemporal structure of the ozone QBO is derived using data from the Microwave Limb Sounder (MLS) aboard the Upper Atmospheric Research Satellite (UARS) for the period from January 1992 to July 1999 over $10^{\circ}$ wide latitude bands covering the tropics and subtropics $\left(40^{\circ} \mathrm{S}-0\right.$ $40^{\circ} \mathrm{N}$ ). Space time variation of the amplitude and phase of the ozone QBO are thereby examined in detail.

\section{Data and analysis}

Vertical profiles of ozone and other species were monitored by the Microwave Limb Sounder (MLS) aboard the Upper Atmospheric Research Satellite (UARS) from October 1991 to July 1999. MLS measures microwave thermal emission, which was then inverted to obtained profiles of temperature, ozone and several other trace molecules (Waters, 1993; Ray et al., 1994). MLS measurements cover a region from $80^{\circ}$ in one hemisphere to $34^{\circ}$ in the opposite hemisphere. The satellite performs a yaw maneuver every 36 days or so to keep some of the instruments protected from the sun's radiation which causes the high-latitude coverage to switch between north and south. MLS data used in this study extends from $40^{\circ} \mathrm{N}$ to $40^{\circ} \mathrm{S}$. Since most of this region $\left(34^{\circ} \mathrm{N}-34^{\circ} \mathrm{S}\right)$ is measured continuously, the time series of daily ozone volume mixing ratio has only a small number of missing points. MLS version 3 level $3 \mathrm{AL}$ data, which are linearly interpolated with respect to latitude along the measurement tangent-point track on to a regular 3 degree latitude grid, were used to generate a zonal-mean time series. The MLS 205-GHz channel ozone measurements used in this study are reliable between 46 and $0.46 \mathrm{hPa}$. The vertical resolution of MLS measurements is approximately $5 \mathrm{~km}$, although vertically interpolated MLS data is included at standard UARS levels in between MLS measurements. The vertical spacing of level $3 \mathrm{AL}$ data is $\sim 2.5 \mathrm{~km}$. Data on ozone volume mixing ratio are stored as IEEE files on the website: http://daac.gsfc.nasa.gov/data/dataset/UARS/MLS/.

Ozone volume mixing ratios are averaged over $10^{\circ}$ wide latitudinal belts ranging from $40^{\circ} \mathrm{S}$ to $40^{\circ} \mathrm{N}\left(40-30^{\circ} \mathrm{S}, 30\right.$ $20^{\circ} \mathrm{S}, 20-10^{\circ} \mathrm{S}, 10^{\circ} \mathrm{S}-0,0-10^{\circ} \mathrm{N}, 10-20^{\circ} \mathrm{N}, 20-30^{\circ} \mathrm{N}$, and $40-30^{\circ} \mathrm{N}$ ). To estimate the monthly means, daily ozone VMRs are averaged over the month. Thus, time series of zonally averaged, monthly-mean ozone VMR are obtained for every pressure level from 46 to $0.68 \mathrm{hPa}$ - i.e. an approximate altitude range of 20 to $50 \mathrm{~km}$ over every $10^{\circ}$ latitude belt. Figure 1 displays the time series of zonal monthlymean ozone VMR over the $0-10^{\circ} \mathrm{N}$ band for the period January 1992 to July 1999 at two representative pressure levels $(10 \mathrm{hPa}$ and $31 \mathrm{hPa})$. Climatological means are obtained from MLS data. Gaps between the data points (as evident in Fig. 1) are filled with the climatological means before the application of wavelet analysis. In order to avoid the influence of Mount Pinatubo eruption effects MLS data considered in this study are for the period July 1992 to July 1999. Climatological means are used for January to June 1992 thus a time series for almost four QBO cycles (1992-1999) is obtained. In order to remove the effects of signals other than the QBO - that is, natural periodic signals like the seasonal cycle and 
11-year solar cycle as well as the linear trend - we use a regression model which is an extended version of the model of Stolarski et al. (1991) and Randel and Cobb (1994). The general expression for the regression model equation can be written as follows:

$\theta(t, z)=\alpha(z)+\beta(z) . \operatorname{Trend}(t)+\delta(z) \cdot \operatorname{Solar}(t)+\operatorname{resid}(t)$

Here, $\alpha(z), \beta(z)$ and $\delta(z)$ are the time-dependent seasonal, trend and solar flux coefficients The Model uses the harmonic expansion to calculate coefficients $\alpha, \beta, \gamma$, and $\delta$. The harmonic expansion for $\alpha(t)$ is given as:

$$
\begin{aligned}
\alpha(t)= & A 0+A 1 \cos \omega t+A 2 \sin \omega t+A 3 \cos 2 \omega t \\
& +A 4 \sin 2 \omega t+A 5 \cos 3 \omega t+A 6 \sin 3 \omega t \\
& +A 7 \cos 4 \omega t+A 8 \sin 4 \omega t
\end{aligned}
$$

Where $\omega=2 \pi / 12 ; A 0, A 1, A 2 \ldots$ are constants and $t(t=1$, $2 \ldots n)$ is the time index. $\alpha, \beta$ and $\delta$ are calculated at every altitude. Since the F10.7 solar radio flux and the $205 \mathrm{~nm}$ solar flux (Mg II index) show very good correlation (99.9\%) (Thuillier and Burinsma, 2001) and the Mg II Index shows good correlation with UV and EUV solar cycle variations, we used the F10.7 indices as solar proxy $(\operatorname{solar}(t))$, respectively, and $\operatorname{resid}(t)$ represents the residuals. The model performs multiple regression analysis of time series at each given pressure level. Residuals obtained from the regression model (at every pressure level) which are free from the effects of seasonal cycle, linear trend and 11 year solar cycle are then subjected to wavelet analysis for analyzing localized variation of the QBO within a time series. Wavelet analysis includes different wavelet functions such as windowed Fourier transform, wavelet transform, normalization, wavelet power spectrum etc. Main advantage of the Wavelet analysis over other techniques is that it analyzes localized variations of power within a time series. By decomposing a time series into time-frequency space, one is able to determine the dominant modes of variability and their variation with time.

The wavelet transform used here is described in detail by Torrence and Compo (1998). The basic wavelet chosen is the Morlet wavelet, which consists of a plane wave modulated by a Gaussian:

$\Psi_{0}=\pi^{1 / 4} e^{i \omega} 0^{\eta} e^{-\eta 2 / 2}$

Here $\omega_{0}$ is the non-dimensional frequency, taken as $6 . \quad \eta$ is non-dimensional time parameter. The continuous wavelet transform of a discrete time series $\mathrm{Xn}$, with equal time spacing $\delta \mathrm{t}$ is defined as:

$W n(s)=\sum_{n^{\prime}=0}^{N-1} X n \psi *\left[\frac{\left(n^{\prime}-n\right) \delta}{t} s\right]$

where the (*) indicates the complex conjugate and " $s$ " indicates the wavelet scale (period). By varying the wavelet scale and translating along the time axis, one obtains the amplitude

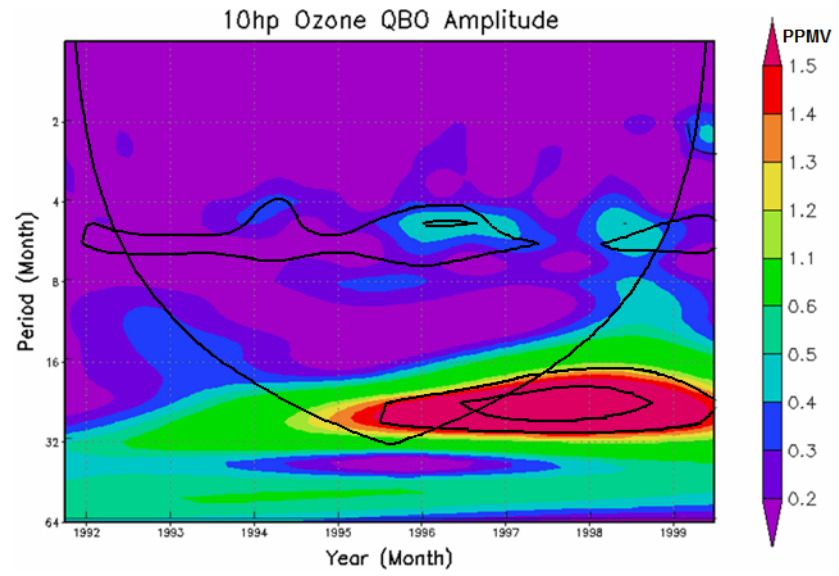

Fig. 2. Variation of amplitude of ozone QBO with time over 0$10^{\circ} \mathrm{N}$ latitudinal belt, thick closed contour indicate $95 \%$ significance levels and U-shape curve indicate Cone Of Influence (COI).

versus scale relationship and the variation of amplitude with time.

While dealing with finite-length time series, errors will occur at the beginning and end of the wavelet power spectrum, as it assumes the data is cyclic. One solution to minimize the error is to pad the end of the time series with zeroes before doing the wavelet transform and then remove them afterward. Hence, the time series is padded with sufficient zeroes to bring the total length $N$ up to the next-higher power of two, thus limiting the edge effects and speeding up the process. Padding with zeroes introduces discontinuities at the endpoints and, as one goes to larger scales, decreases the amplitude near the edges as more zeroes enter the analysis. The cone of influence (COI) is the region of the wavelet spectrum in which edge effects become important and is defined here as the e-folding time for the autocorrelation of wavelet power at each scale. This e-folding time is chosen so that the wavelet power for a discontinuity at the edge drops by a factor $e^{-2}$ and ensures that the edge effects are negligible beyond this point. In Fig. 2, the region below the thin U-shaped curve indicates the COI.

The period of the QBO varies between 22 and 34 months, with an average period of slightly more than 28 months (Baldwin et al., 2001). In the present analysis the amplitudes that are significant at a $95 \%$ confidence level and that have periods between 22 and 34 months are assumed to be QBO signals. These amplitudes are averaged for all the years, at every pressure level, over every latitudinal belt, in order to get a three-dimensional view of amplitude variation with height and time. In order to study the phase relationship of the ozone QBO with zonal wind QBO, $30 \mathrm{hPa}$ Singapore $\left(1^{\circ} \mathrm{N}\right)$ zonal winds are obtained from http://strat-www.met. fu-berlin.de/products/cdrom/html/section5.html.

In the discussion that follows, we group the results by pressure levels, taking 100-46 hPa as the lower stratosphere, 

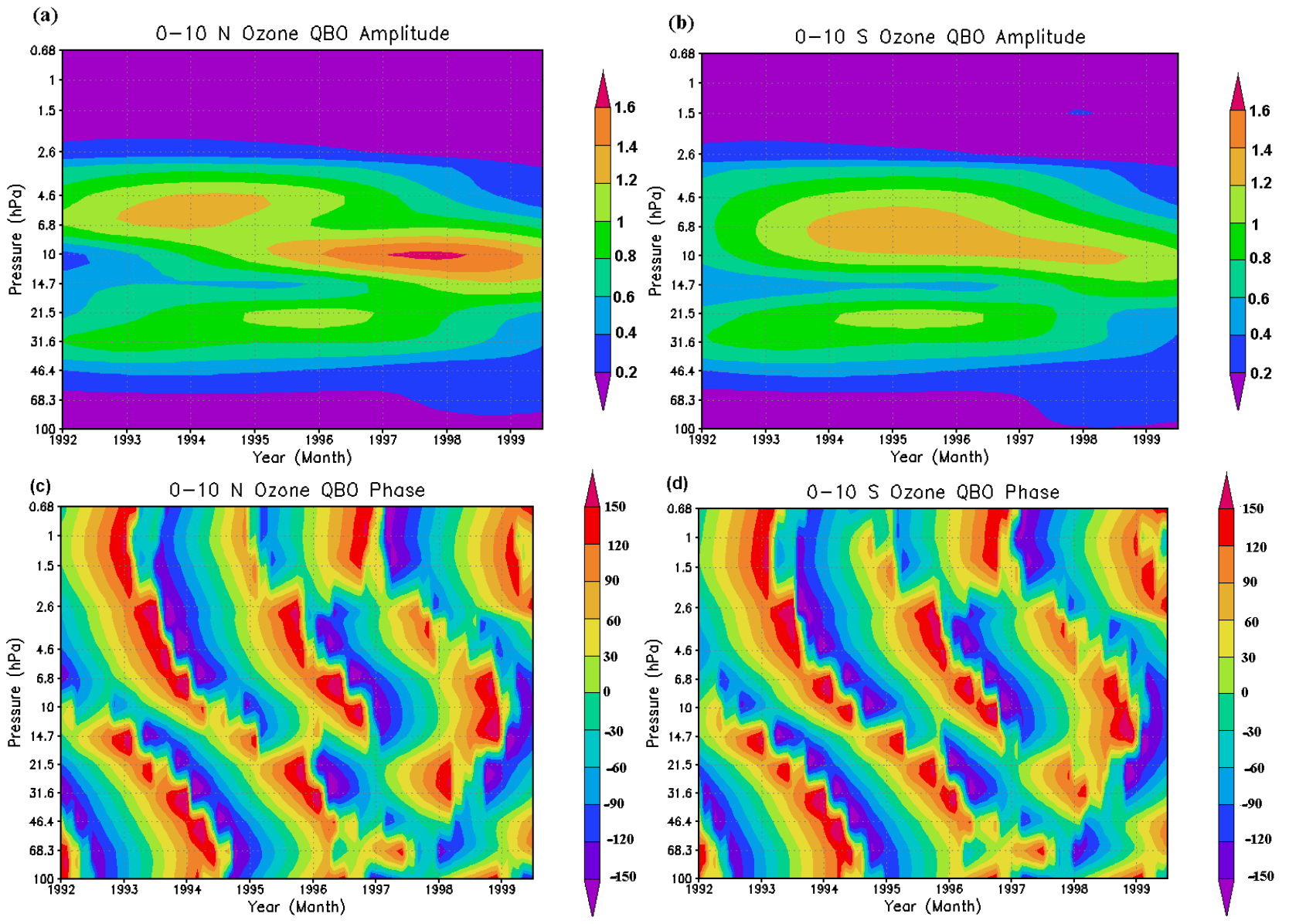

Fig. 3. Variation of amplitude of ozone QBO in time-height domain over (a) $0-10^{\circ} \mathrm{N}$ and (b) $0-10^{\circ} \mathrm{S}$. Variation of phase of ozone QBO in time-height domain over (c) $0-10^{\circ} \mathrm{N}$ and (d) $0-10^{\circ} \mathrm{S}$.

46-10 $\mathrm{hPa}$ as the middle stratosphere, and $10-0.68 \mathrm{hPa}$ as the upper stratosphere. Positive QBO phase in ozone is present when the zonal winds are westerly while negative phase corresponds to easterlies. The phase of the QBO is expressed in degrees (it may vary between 0-360 degrees). The term “ozone QBO” represents quasi-biennial oscillation in ozone.

\section{Results and discussions}

3.1 Spatiotemporal variation of the ozone QBO near the equator

Figure 2 displays the inter-annual variation of amplitude of different oscillations in ozone over the stratospheric height of $0-10^{\circ} \mathrm{N}$ latitudinal belt. Thick closed contours indicate the $95 \%$ significance level and the region below the thin $\mathrm{U}$ shaped curve indicates the cone of influence (COI). This figure clearly shows that tropical ozone exhibits both a QBO variation (22-34 months periodicity) and a Semi-Annual Oscillation (SAO; 5-6 months periodicity), each of which are significant at the $95 \%$ confidence level. In addition, it is clear from the figure that the SAO is completely outside of the COI, indicating that the analysis is not affected by edge effects. This implies that the SAO amplitude has not been underestimated. On the other hand, some portion of the amplitude of the QBO is inside the COI, which will be affected by edge effects. Therefore, the QBO may be underestimated by $0.1 \mathrm{ppmv}$.

Figure $3 \mathrm{a}$ and $\mathrm{b}$ displays the inter-annual variation in amplitude of the ozone QBO over the $0-10^{\circ} \mathrm{N}$ and $0-10^{\circ} \mathrm{S}$ latitudinal belts, respectively. The amplitude of the equatorial ozone QBO varies from $0.2 \mathrm{ppmv}$ to $1.6 \mathrm{ppmv}$. A double peak structure is quite evident in both hemispheres with centers at $22 \mathrm{hPa}$ (middle stratosphere) and $9 \mathrm{hPa}$ (upper stratosphere) and with a node at $14 \mathrm{hPa}$. The upper stratospheric maximum is stronger than the middle stratospheric maximum. In the past, many studies (Zawodny and McCormick, 1991; Hasebe, 1994; Randel and Wu, 1996; Dunkerton, 2001) have reported similar double peak structures over this region at similar pressure levels. The maximum amplitude 
(>1.4 ppmv) near $10 \mathrm{hPa}$ is observed for the years 19971999 over the Northern Hemisphere whereas in the Southern Hemisphere it is observed for the years 1994-1998. From HALOE ozone data, Randel et al. (1999) reported amplitude of $\sim 1 \mathrm{ppmv}$ near $30 \mathrm{hPa}$ and $9 \mathrm{hPa}$ at the equator. From SAGE data, Zawodny and McCormick (1991) have reported QBO amplitude $\sim 10 \%$ near $22 \mathrm{hPa}$. These results agree well with our results. On the other hand, the amplitude (4\%) obtained from model simulation (Chipperfield et al., 1994; Jones et al., 1998; McCormack et al., 2007) is much less than the amplitude obtained from satellite data.

The phase of the ozone QBO over $0-10^{\circ} \mathrm{N}$ and $0-10^{\circ} \mathrm{S}$ is shown in Fig. 3c and d, respectively. Downward propagation of the QBO phase with alternating westerly (positive) and easterly (negative) phases are quite evident. A broad band of positive phase that is associated with a westerly shear zone descends from $0.68 \mathrm{hPa}$ in mid 1993 to $100 \mathrm{hPa}$ in mid 1995. This is followed by narrow band of negative anomalies, associated with an easterly shear zone that descends from $0.68 \mathrm{hPa}$ in late 1994 to $100 \mathrm{hPa}$ in late 1998 . The easterly phase is stronger than the westerly phase and the transition from westerlies to easterlies is sharper than the transition from easterlies to westerlies. These results are in agreement with Baldwin et al. (2001). The descent rates of the westerly and easterly phases are tabulated in Table 1. It is observed that decent rates of easterly phase are stronger than that of the westerly phase in both $0-10^{\circ} \mathrm{N}$ and $0-10^{\circ} \mathrm{S}$ belts. The descent rates are slower in the Southern Hemisphere than in the Northern Hemisphere.

To study the lag/lead relationship of the phase of the ozone QBO with respect to the phase of the QBO in circulation, regression analysis followed by wavelet analysis of Singapore zonal wind has been carried out. The lag in month is defined to be the lag for which the correlation coefficient is highest and Student " $t$ " test values are significant at $95 \%$ confidence level. Table 2 shows the vertical variation of lag in month and the correlation coefficient of the QBO in Singapore zonal winds with the $\mathrm{QBO}$ in ozone over $0-10^{\circ} \mathrm{N}$ belt. In the upper stratosphere the QBO in winds lag the ozone QBO up to quarter cycle and they are out of phase. The reason for observed lag may be that both ozone and wind (hence QBO) are temperature dependant. Variations in temperature will affect both winds and ozone. Moreover, ozone reactions are temperature dependant (Fadnavis and Beig, 2006) which will further cascade this effect. They are in phase with zero lag in lower and middle stratosphere. From Nimbus-7 TOMS ozone Echer et al. (2004) also reported that total ozone is nearly in phase with the QBO in circulation at the equatorial region.

3.2 Spatiotemporal variation of the ozone QBO in the tropical latitudes

Figure $4 \mathrm{a}$ and $\mathrm{b}$ exhibit the time variation of the amplitude of ozone QBO over $10-20^{\circ} \mathrm{N}$ and $10-20^{\circ} \mathrm{S}$ latitudinal belts,
Table 1. Vertical variation of descent rate of westerly and easterly phase over different latitudinal belts.

\begin{tabular}{|c|c|c|}
\hline & Westerly phase & Easterly phase \\
\hline \multicolumn{3}{|c|}{ Ozone QBO $-0-10^{\circ} \mathrm{N}$} \\
\hline Lower stratosphere & $0.83 \mathrm{~km} /$ month & $1.62 \mathrm{~km} / \mathrm{month}$ \\
\hline Middle stratosphere & $0.46 \mathrm{~km} / \mathrm{month}$ & $0.52 \mathrm{~km} /$ month \\
\hline Upper stratosphere & $1.4 \mathrm{~km} / \mathrm{month}$ & $1.6 \mathrm{~km} / \mathrm{month}$ \\
\hline \multicolumn{3}{|c|}{ Ozone QBO $0-10^{\circ} \mathrm{S}$} \\
\hline Lower stratosphere & $0.83 \mathrm{~km} /$ month & $1.1 \mathrm{~km} /$ month \\
\hline Middle stratosphere & $0.45 \mathrm{~km} /$ month & $0.45 \mathrm{~km} /$ month \\
\hline Upper stratosphere & $1.0 \mathrm{~km} / \mathrm{month}$ & $1.14 \mathrm{~km} /$ month \\
\hline \multicolumn{3}{|c|}{ Ozone QBO $10-20^{\circ} \mathrm{N}$} \\
\hline Lower stratosphere & $0.5 \mathrm{~km} / \mathrm{month}$ & $0.5 \mathrm{~km} /$ month \\
\hline Middle stratosphere & $0.48 \mathrm{~km} / \mathrm{month}$ & $0.52 \mathrm{~km} /$ month \\
\hline Upper stratosphere & Ascent above $2 \mathrm{hPa}$ & Ascent above $2 \mathrm{hPa}$ \\
\hline \multicolumn{3}{|c|}{ Ozone QBO $10-20^{\circ} \mathrm{S}$} \\
\hline Lower stratosphere & $0.33 \mathrm{~km} / \mathrm{month}$ & $0.38 \mathrm{~km} / \mathrm{month}$ \\
\hline Middle stratosphere & $0.45 \mathrm{~km} / \mathrm{month}$ & $0.47 \mathrm{~km} / \mathrm{month}$ \\
\hline Upper stratosphere & Ascent above $2 \mathrm{hPa}$ & Ascent above $2 \mathrm{hPa}$ \\
\hline \multicolumn{3}{|c|}{ Ozone QBO $20-30^{\circ} \mathrm{N}$} \\
\hline Lower stratosphere & $1.3 \mathrm{~km} / \mathrm{month}$ & $1.3 \mathrm{~km} /$ month \\
\hline Middle stratosphere & $0.73 \mathrm{~km} / \mathrm{month}$ & $0.73 \mathrm{~km} / \mathrm{month}$ \\
\hline Upper stratosphere & Ascent above $2 \mathrm{hPa}$ & Ascent above $2 \mathrm{hPa}$ \\
\hline \multicolumn{3}{|c|}{ Ozone QBO $20-30^{\circ} \mathrm{S}$} \\
\hline Lower stratosphere & $0.5 \mathrm{~km} /$ month & $0.6 \mathrm{~km} / \mathrm{month}$ \\
\hline Middle stratosphere & $0.4 \mathrm{~km} /$ month & $0.45 \mathrm{~km} / \mathrm{month}$ \\
\hline Upper stratosphere & Ascent above $2 \mathrm{hPa}$ & Ascent above $2 \mathrm{hPa}$ \\
\hline \multicolumn{3}{|c|}{ Ozone QBO $30-40^{\circ} \mathrm{N}$} \\
\hline Lower stratosphere & $1.25 \mathrm{~km} / \mathrm{month}$ & $1.25 \mathrm{~km} / \mathrm{month}$ \\
\hline Middle stratosphere & $0.78 \mathrm{~km} /$ month & $0.64 \mathrm{~km} / \mathrm{month}$ \\
\hline Upper stratosphere & $1.2 \mathrm{~km} / \mathrm{month}$ & $0.94 \mathrm{~km} /$ month \\
\hline \multicolumn{3}{|c|}{ Ozone QBO $30-40^{\circ} \mathrm{S}$} \\
\hline Lower stratosphere & $0.5 \mathrm{~km} /$ month & $0.41 \mathrm{~km} / \mathrm{month}$ \\
\hline Middle stratosphere & $0.55 \mathrm{~km} / \mathrm{month}$ & $0.55 \mathrm{~km} / \mathrm{month}$ \\
\hline Upper stratosphere & Ascent above $2 \mathrm{hPa}$ & Ascent above $2 \mathrm{hPa}$ \\
\hline
\end{tabular}

respectively. The Northern Hemisphere shows a strong amplitude (>1.4 ppmv) near $10 \mathrm{hPa}$ during 1997-1999. Over the Southern Hemisphere, the maximum amplitude (1$1.4 \mathrm{ppmv}$ ) is observed near $10 \mathrm{hPa}$ during $1992-1994$. QBO amplitude in the Northern Hemisphere is stronger than that of the Southern Hemisphere. Li et al. (1997) found that the QBO in circulation over the Northern Hemisphere is generally stronger than in the Southern Hemisphere, which agrees well with the present results. The phase of the ozone QBO over $10-20^{\circ} \mathrm{N}$ and $10-20^{\circ} \mathrm{S}$ is shown in Fig. $4 \mathrm{c}$ and d, respectively. From Table 1 it is quite evident that the rate of descent is slower in the Southern Hemisphere than the Northern 
Table 2. Vertical variation of lag correlation of Singapore zonal wind QBO with ozone QBO over $0-10^{\circ} \mathrm{N}$ belt.

\begin{tabular}{lccc}
\hline $\begin{array}{l}\text { Pressure level } \\
(\mathrm{hPa})\end{array}$ & $\begin{array}{c}\text { lag (months) Singapore zonal wind } \\
\text { QBO with ozone QBO at } 0-10^{\circ} \mathrm{N}\end{array}$ & $\begin{array}{c}\text { Maximum correlation } \\
\text { coefficient }\end{array}$ & $\begin{array}{c}\text { Student t } \\
\text { test value }\end{array}$ \\
\hline $3.2 \mathrm{hPa}$ & 4 months & -0.5 & -6.8 \\
4.6 & 3 months & -0.631 & -7.6 \\
$10 \mathrm{hPa}$ & 7 months & -0.6 & -6.9 \\
$14.7 \mathrm{hPa}$ & 8 months & -0.64 & -7.9 \\
$21.5 \mathrm{hPa}$ & 0 months & +0.5 & 6.66 \\
$31 \mathrm{hPa}$ & 0 months & 0.699 & 9.3 \\
$46 \mathrm{hPa}$ & 0 months & 0.5 & 5.4 \\
$100 \mathrm{hPa}$ & 0 months & 0.7 & 11.04 \\
\hline
\end{tabular}
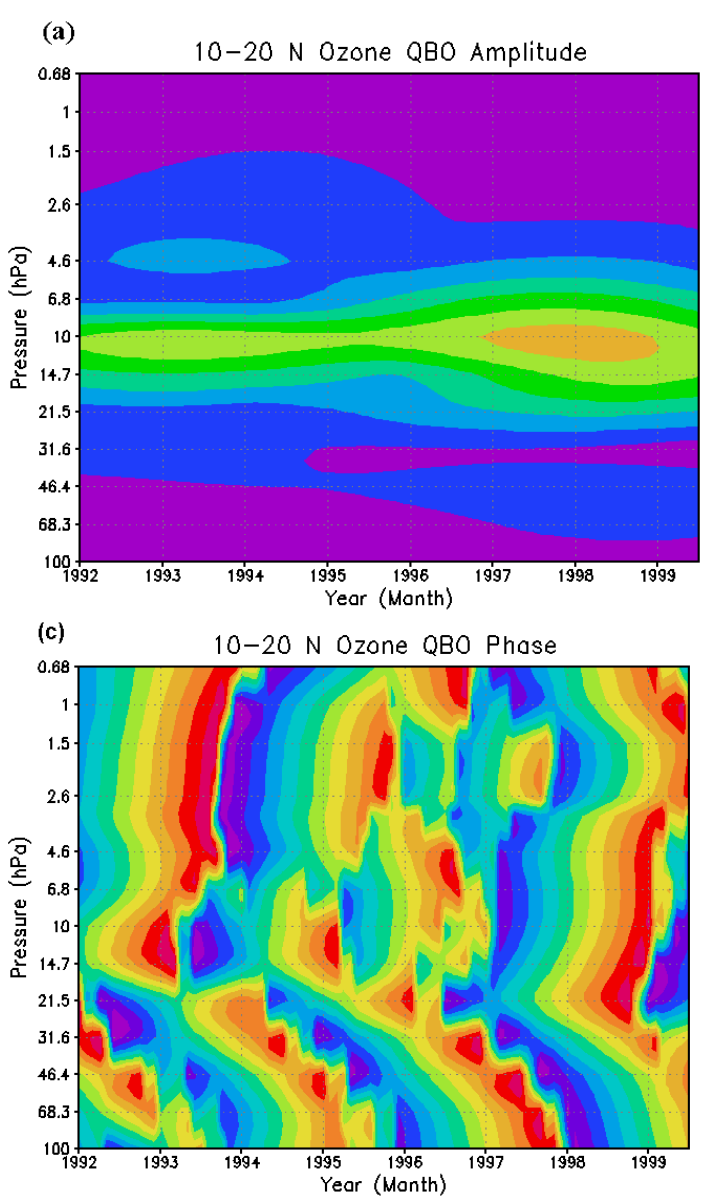

(b)
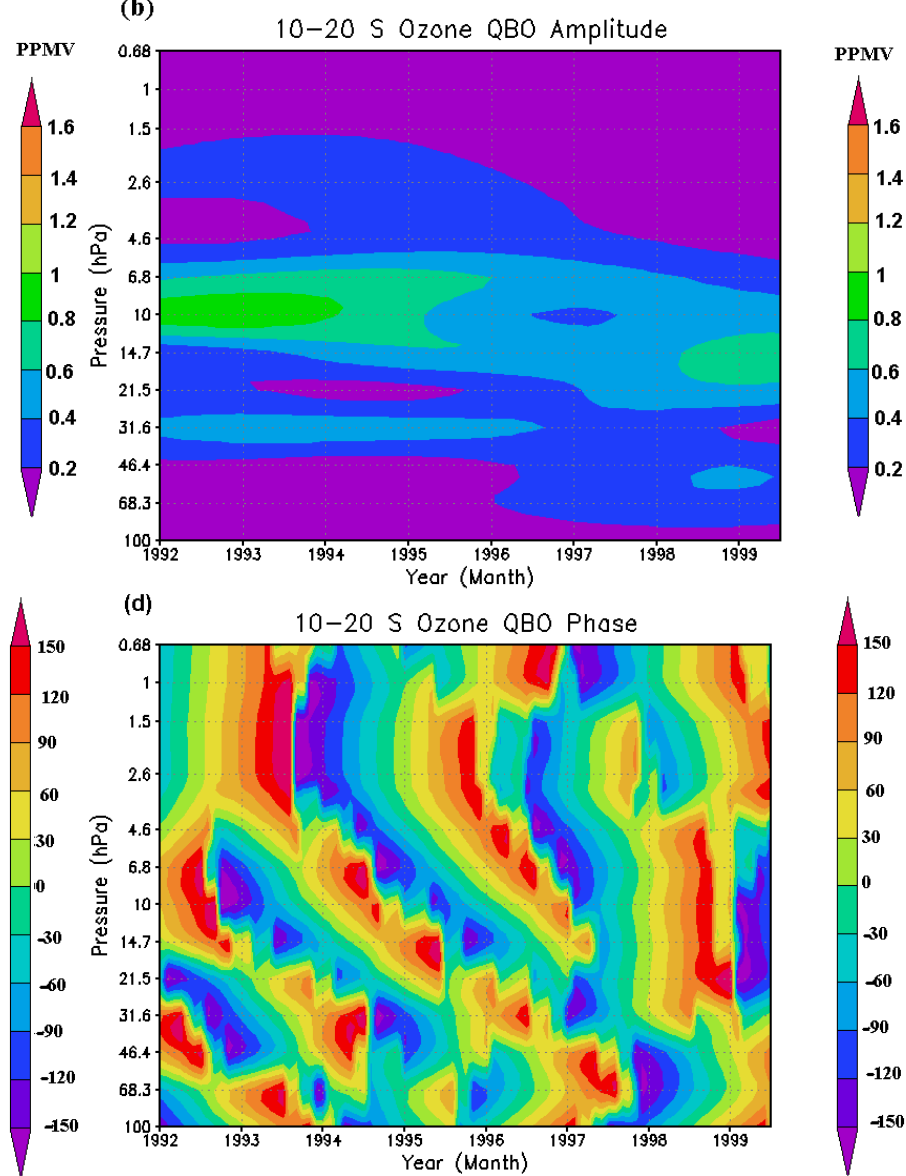

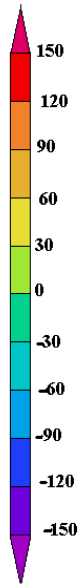

Fig. 4. Variation of amplitude of ozone QBO in time-height domain over (a) $10-20^{\circ} \mathrm{N}$ and (b) $10-20^{\circ} \mathrm{S}$. Variation of phase of ozone QBO in time-height domain over (c) $10-20^{\circ} \mathrm{N}$ and (d) $10-20^{\circ} \mathrm{S}$.

Hemisphere. Downward propagation of the QBO with alternate easterly and westerly phase is quite fast in the upper stratosphere. In the upper stratosphere, above $2 \mathrm{hPa}$ of both the belts, the ozone QBO anomalies ascend with altitude. Similar results are also reported by Fadnavis et al. (2007). They reported that a subtropical QBO occurs with the pres- ence of a return arm of the equatorial QBO circulation. Its ascent in the subtropics is associated with westerly equatorial shear. Hence this upward propagation may be due to advection of ozone out of tropics into subtropics due to the seasonally varying secondary meridional circulation induced by the QBO. 

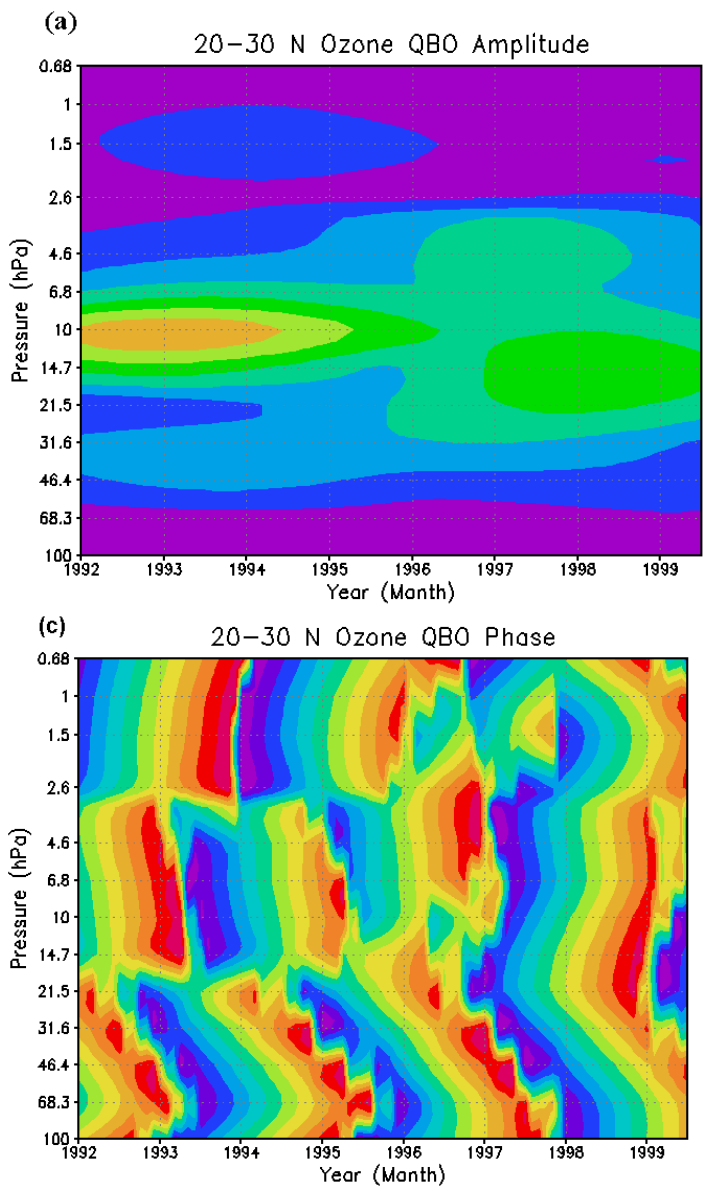
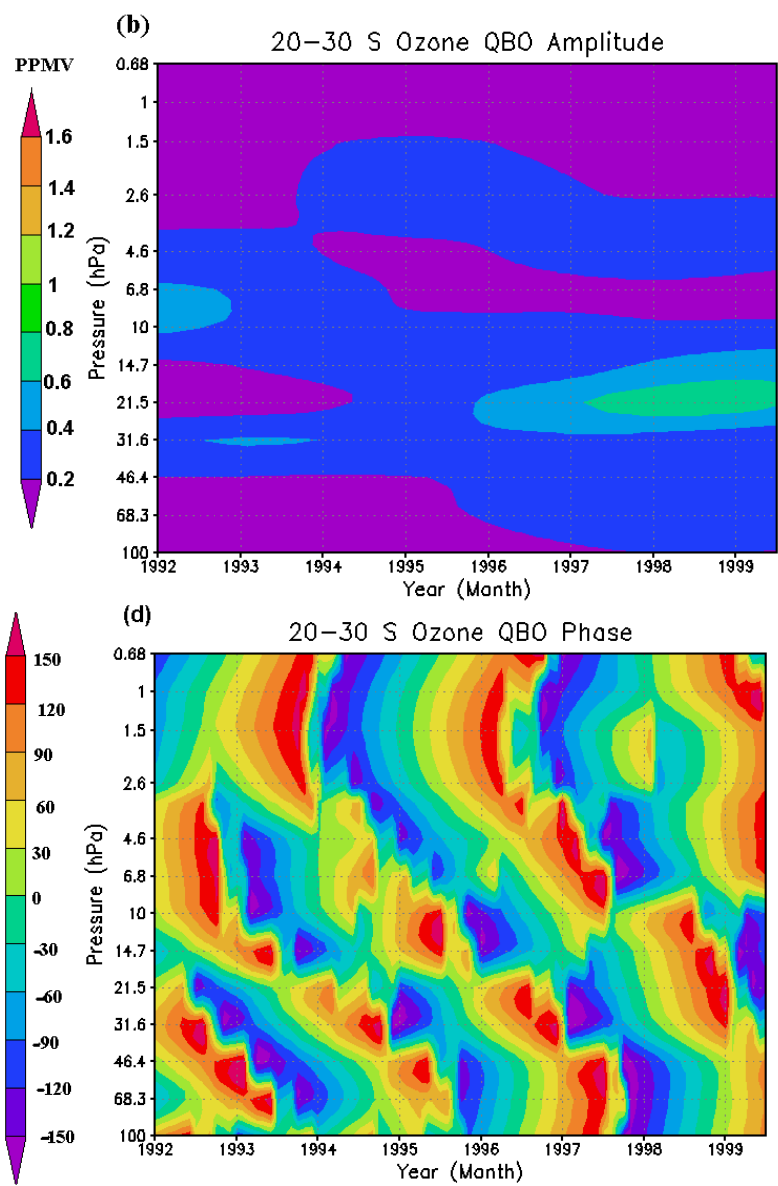

Fig. 5. Variation of amplitude of ozone QBO in time-height domain over (a) $20-30^{\circ} \mathrm{N}$ and (b) $20-30^{\circ} \mathrm{S}$. Variation of phase of ozone QBO in time-height domain over (c) $20-30^{\circ} \mathrm{N}$ and (d) $20-30^{\circ} \mathrm{S}$.

Table 3 indicates lag correlation of the ozone QBO over $10-20^{\circ} \mathrm{N}$ with the ozone QBO over the equatorial belt 0 $10^{\circ} \mathrm{N}$. Near the stratopause, the ozone QBO over $10-20^{\circ} \mathrm{N}$, lags the equatorial ozone QBO by $2-5$ months. However the ozone QBO over southern belt $\left(10-20^{\circ} \mathrm{S}\right)$ at these pressure levels is in phase with the equatorial $\left(0-10^{\circ} \mathrm{S}\right)$ ozone QBO. In the lower and middle stratosphere no definite relation is observed. At some pressure level the ozone QBO over $10-20^{\circ} \mathrm{N}-\mathrm{S}$ shows zero lag with the equatorial ozone QBO while at others it lags by $3-9$ months.

Figure $5 \mathrm{a}$ and $\mathrm{b}$ displays the vertical structure of the amplitude of ozone QBO over $20-30^{\circ} \mathrm{N}$ and $20-30^{\circ} \mathrm{S}$ latitudinal belt, respectively. Over the Northern Hemisphere, the maximum amplitude (1.2-1.4 ppmv) is observed near $10 \mathrm{hPa}$ during 1992-1994 and another high (1-1.2 ppmv) is observed near $22 \mathrm{hPa}$ during 1997-1999. The Southern Hemisphere shows a peak near $22 \mathrm{hPa}$ during 1998-1999. A peak near $10 \mathrm{hPa}$ is seen over the Northern Hemisphere but does not appear over the Southern Hemisphere. The vertical structure of the phase of the ozone QBO over $20-30^{\circ} \mathrm{N}$ and $20-30^{\circ} \mathrm{S}$ is shown in Fig. 5c and d, respectively. It shows that the easterly phase is stronger than the westerly phase and the transition from westerlies to easterlies is sharper than the transition from easterlies to westerlies.

The rate of descent in the lower and middle stratosphere are tabulated in Table 1. The rate of descent is slower in the Southern Hemisphere than in the Northern Hemisphere. Similar to $10-20^{\circ} \mathrm{N}-\mathrm{S}$ belt, the ozone QBO over $20-30^{\circ} \mathrm{N}-$ $\mathrm{S}$ belts also shows ascent at the altitudes above $2 \mathrm{hPa}$. Similar results are also observed over $10-20^{\circ}$ belt. This Ascent of the ozone QBO over tropical and subtropical belts may be due to advection of ozone out of tropics into subtropics due to seasonally varying secondary meridional circulation induced by the QBO (Fadnavis et al., 2007).

The lag correlation of ozone over $20-30^{\circ} \mathrm{N}-\mathrm{S}$ with the ozone QBO over the equatorial belt $0-10^{\circ} \mathrm{N}-\mathrm{S}$ is tabulated in Table 3. At most of the pressures levels, the ozone QBO lags, and is out of phase with the equatorial ozone QBO. At some pressure levels $(2.6 \mathrm{hPa}, 3.2 \mathrm{hPa}, 4.6 \mathrm{hPa}, 14.7 \mathrm{hPa}$ over $20-30^{\circ} \mathrm{N}$ and $4.6 \mathrm{hPa}, 14.7 \mathrm{hPa}$ over $20-30^{\circ} \mathrm{S}$ ) there is zero 
Table 3. Vertical variation of lag correlation of ozone QBO over the equatorial belt $(0-10 \mathrm{~N}-\mathrm{S})$ with ozone QBO at different latitudinal belts.

\begin{tabular}{|c|c|c|c|c|c|c|}
\hline $\begin{array}{c}\text { Pressure } \\
(\mathrm{hPa})\end{array}$ & $\begin{array}{c}\text { lag (months) of } \\
10-20^{\circ} \mathrm{N} \\
\text { ozone QBO } \\
\text { with the } 0-10^{\circ} \mathrm{N} \\
\text { ozone QBO }\end{array}$ & $\begin{array}{c}\text { lag (months) of } \\
10-20^{\circ} \mathrm{S} \\
\text { ozone QBO } \\
\text { with the } 0-10^{\circ} \mathrm{S} \\
\text { ozone QBO }\end{array}$ & $\begin{array}{c}\text { lag (months) of } \\
20-30^{\circ} \mathrm{N} \\
\text { ozone QBO } \\
\text { with the } 0-10^{\circ} \mathrm{N} \\
\text { ozone QBO }\end{array}$ & $\begin{array}{c}\text { lag (months) of } \\
20-30^{\circ} \mathrm{S} \\
\text { ozone QBO } \\
\text { with the } 0-10^{\circ} \mathrm{S} \\
\text { ozone QBO }\end{array}$ & $\begin{array}{c}\text { lag (months) of } \\
30-40^{\circ} \mathrm{N} \\
\text { ozone QBO } \\
\text { with the } 0-10^{\circ} \mathrm{N} \\
\text { ozone QBO }\end{array}$ & $\begin{array}{c}\text { lag (months) of } \\
30-40^{\circ} \mathrm{S} \\
\text { ozone QBO } \\
\text { with the } 0-10^{\circ} \mathrm{S} \\
\text { ozone QBO }\end{array}$ \\
\hline 0.68 & 3 & 0 & 5 & 3 & 6 & 2 \\
\hline 1.0 & 2 & 0 & 2 & 4 & 3 & 2 \\
\hline 1.5 & 5 & 0 & $6^{\mathrm{a}}$ & 14 & $5^{\mathrm{a}}$ & 6 \\
\hline 2.6 & 0 & 0 & 0 & $6^{\mathrm{a}}$ & $8^{a}$ & $5^{\mathrm{a}}$ \\
\hline 3.2 & 0 & 0 & 0 & $1^{\mathrm{a}}$ & $0^{\mathrm{a}}$ & $3^{\mathrm{a}}$ \\
\hline 4.6 & $0^{\mathrm{a}}$ & $0^{\mathrm{a}}$ & $0^{\mathrm{a}}$ & $0^{\mathrm{a}}$ & $0^{\mathrm{a}}$ & $0^{\mathrm{a}}$ \\
\hline 6.8 & 0 & $9^{a}$ & 3 & $1^{\mathrm{a}}$ & $3^{\mathrm{a}}$ & $3^{\mathrm{a}}$ \\
\hline 10 & $8^{a}$ & 0 & $5^{\mathrm{a}}$ & $4^{\mathrm{a}}$ & $6^{\mathrm{a}}$ & $5^{\mathrm{a}}$ \\
\hline 14.7 & 0 & 0 & 0 & 0 & 0 & 0 \\
\hline 21.5 & 0 & 0 & $5^{\mathrm{a}}$ & $4^{\mathrm{a}}$ & 0 & 0 \\
\hline 31.6 & $4^{\mathrm{a}}$ & $7^{\mathrm{a}}$ & $2^{\mathrm{a}}$ & $3^{\mathrm{a}}$ & $7^{\mathrm{a}}$ & $10^{\mathrm{a}}$ \\
\hline 46.4 & 3 & $8^{\mathrm{a}}$ & 3 & $1^{\mathrm{a}}$ & $8^{a}$ & $8^{a}$ \\
\hline 68.3 & 7 & 2 & 4 & 12 & $11^{\mathrm{a}}$ & $9^{\mathrm{a}}$ \\
\hline 100 & $0^{\mathrm{a}}$ & 0 & $3^{\mathrm{a}}$ & $7^{\mathrm{a}}$ & $3^{\mathrm{a}}$ & $3^{\mathrm{a}}$ \\
\hline
\end{tabular}

a indicates out of phase

lag between the ozone QBO over $20-30^{\circ}$ belt and the equatorial ozone QBO.

\subsection{Spatiotemporal variation of the ozone QBO in the subtropics}

The vertical structure of the amplitude of the ozone QBO over $30-40^{\circ} \mathrm{N}$ and $30-40^{\circ} \mathrm{S}$ is shown in Fig. 6a and b, respectively. The Northern Hemisphere shows two peaks near $14 \mathrm{hPa}$ and $22 \mathrm{hPa}$ during 1992-1994 and 1997-1999, respectively. Over the Southern Hemisphere, the peaks near $14 \mathrm{hPa}$ and $22 \mathrm{hPa}$ are reduced in duration and vertical extent as compared to the Northern Hemisphere. These double peaks (at the similar altitudes) are also reported by Zawodny and McCormick (1991) and Randel and Wu (1996) in SAGE ozone data. Figure $6 \mathrm{c}$ and d exhibits the vertical variation of the phase of the ozone QBO over $30-40^{\circ} \mathrm{N}$ and $30-40^{\circ} \mathrm{S}$, respectively. It exhibits that the easterly phase is stronger than the westerly phase and the transition from westerlies to easterlies is sharper than the transition from easterlies to westerlies.

The rate of descent is slower in the Southern Hemisphere than in the Northern Hemisphere (see Table 1).

The lag correlation of the ozone QBO over $30-40^{\circ} \mathrm{N}-\mathrm{S}$ with the ozone QBO over the equatorial belt (see Table 3) indicates that over most of the altitudes the ozone QBO lags (and is out of out of phase with) the equatorial ozone QBO. It shows zero lag at $14.7 \mathrm{hPa}$ and $21.5 \mathrm{hPa}$. It is important to note that the ozone QBO at all the latitudinal belts (10$20^{\circ} \mathrm{N}-\mathrm{S}, 20-30^{\circ} \mathrm{N}-\mathrm{S}$ and $30-40^{\circ} \mathrm{N}-\mathrm{S}$ ) show zero lag correlation at $4.6 \mathrm{hPa}$ (and out of phase) and 14.7 (and in phase) with the equatorial ozone QBO. Figure $7 \mathrm{~b}$ shows that near the equator, the ozone QBO changes its phase at $22 \mathrm{hPa}$. In Sect. 3.4, it is explained (from Fig. 8) that this node corresponds to zero wind level. This may be the reason for the observed zero lag correlation between the ozone QBO at the equator and other latitudinal belts at these pressure levels.

\subsection{Latitude-height structure of the ozone QBO}

The amplitude of the QBO is averaged for all the years at a pressure level over a selected belt to obtain a single value. Similar averaged QBO amplitude is obtained for all the pressure levels. This procedure is repeated for all the latitudinal belts. Similarly averaged phase values are also obtained for all the pressure levels of all the latitudinal belts. The latitudeheight structure of the amplitude of the ozone QBO and its phase are shown in Fig. 7a and b, respectively. A double peak structure with a maximum near $22 \mathrm{hPa}$ and a $9 \mathrm{hPa}$ center at the equator is quite evident in Fig. 7a. Figure $7 \mathrm{~b}$ shows that the maximum near $22 \mathrm{hPa}$ is out of phase with the maximum near $9 \mathrm{hPa}$ and that a node exists at $14 \mathrm{hPa}$.

This feature has also been observed in SAGE II data by Zawodny and McCormick (1991), Randel and Wu (2007, 1996), and Logan et al. (2003). Dunkerton (2001) also observed a similar double peak structure in ozone, methane, and water vapor QBO anomalies derived from HALOE data. McCormack et al. (2007) reported similar structure in SBUV data. Results of numerical simulation also reported two peaks of about $4 \%$ near 24 and $32 \mathrm{~km}$ (Chipperfield et al., 1994; Jones et al., 1998; McCormack et al., 2007). Kinnersley (1998) reported similar structure in equatorial zonal 

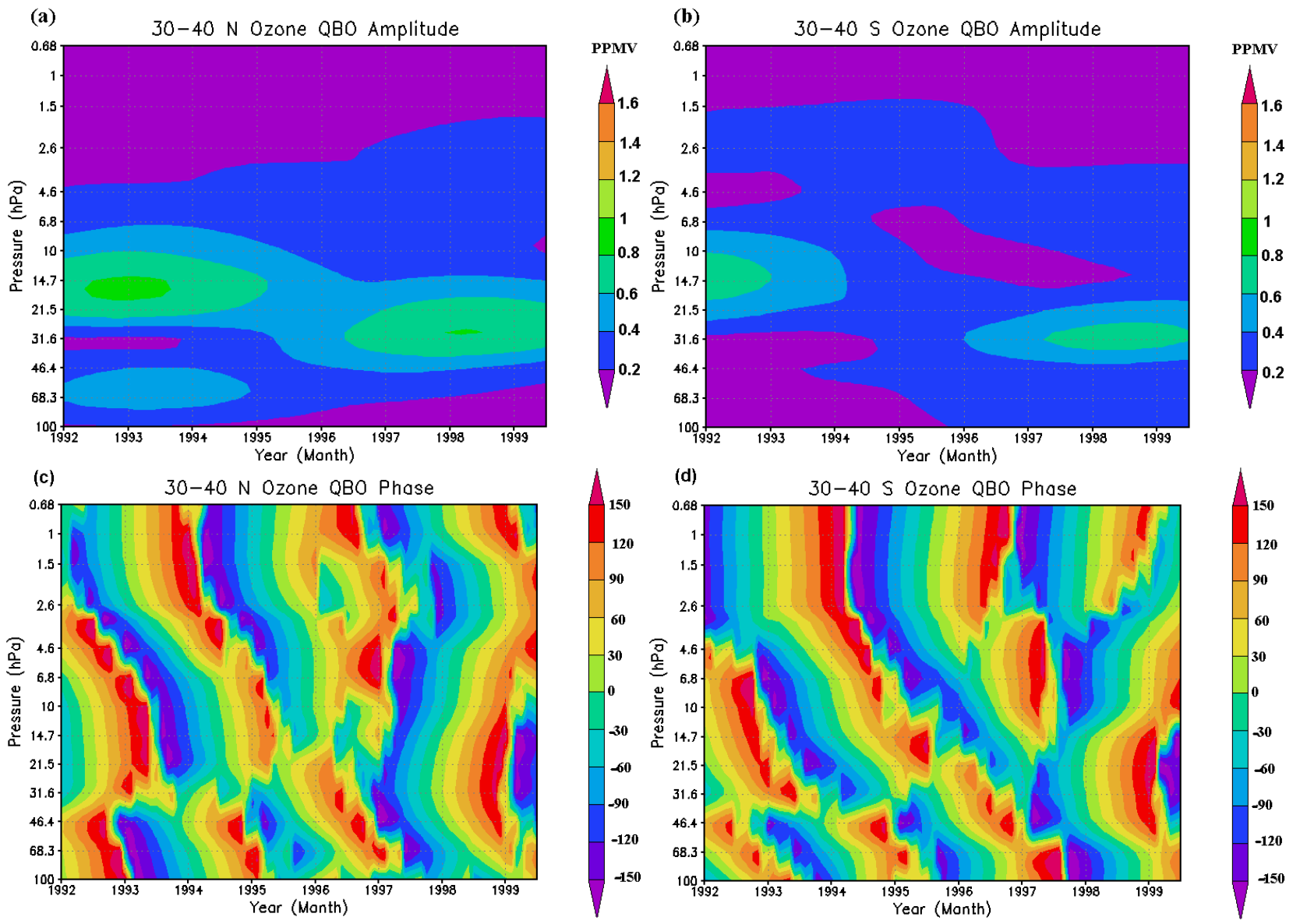

Fig. 6. Variation of amplitude of ozone QBO in time-height domain over (a) 30-40 $\mathrm{N}$ and (b) $30-40^{\circ} \mathrm{S}$. Variation of phase of ozone QBO in time-height domain over (c) $30-40^{\circ} \mathrm{N}$ and (d) $30-40^{\circ} \mathrm{S}$.

winds. He explained that a forcing of the zonal wind near equator will induce a meridional circulation to alter the zonal mean temperature and maintain thermal wind balance. The mean circulation induced by such a forcing can produce a double peak structure symmetric about the equator, with ascent over the equator and descent at about $15^{\circ}$ when the equatorial shear in the zonal wind was easterly (Plumb and Bell, 1982; Dunkerton, 1985).

A similar mechanism is also explained by Choi et al. (2002) and Ribera et al. (2004). They reported that the double peak structure in the latitude-altitude cross-section of tracer's distribution is evidence of the secondary circulation. They explained this with a schematic diagram Fig. 8. Their interpretation states that zonal winds are assumed to be sinusoidal in the vertical direction. The thermal wind relationship requires a warm anomaly in the westerly shear zone and cold anomaly in the easterly shear zone. To maintain these temperature anomalies there exists a region of relative sinking and rising motion in the westerly and easterly shear zones. In the ideal distribution of zonal winds the maximum sinking motion appears in the maximum westerly shear zone, which coincides with the zero zonal wind level (B in Fig. 8). The location of maximum easterly wind coincides with that of the maximum horizontal divergence denoted by either $\mathrm{A}$ or $\mathrm{C}$ in Fig. 8. A double peak structure in tracers is expected at levels near the point of maximum horizontal divergence. The total residual circulation is the sum of the QBO induced vertical circulation and the background annually varying extratropically driven residual circulation. A double peak (22 and $9 \mathrm{hPa}$ in Fig. 7a) appears at the points of maximum divergence (A or $\mathrm{C}$ in Fig. 8), where owing to the QBO circulation, the vertical velocity of the total residual circulation is weaker at the equator than in the subtropics. Node near $14 \mathrm{hPa}$ appears at the zero zonal wind level (B in Fig. 8).

The QBO anomaly changes sign at approximately $\pm 15^{\circ}$ owing to rising motions that compensate the sinking motions at the equator (Cordero and Nathan, 2005; Baldwin et al., 2001; Choi et al., 2002). Ribera et al. (2004) observed that positive and negative maximum meridional wind anomalies are located between $\pm 20^{\circ}$ latitude and are related 


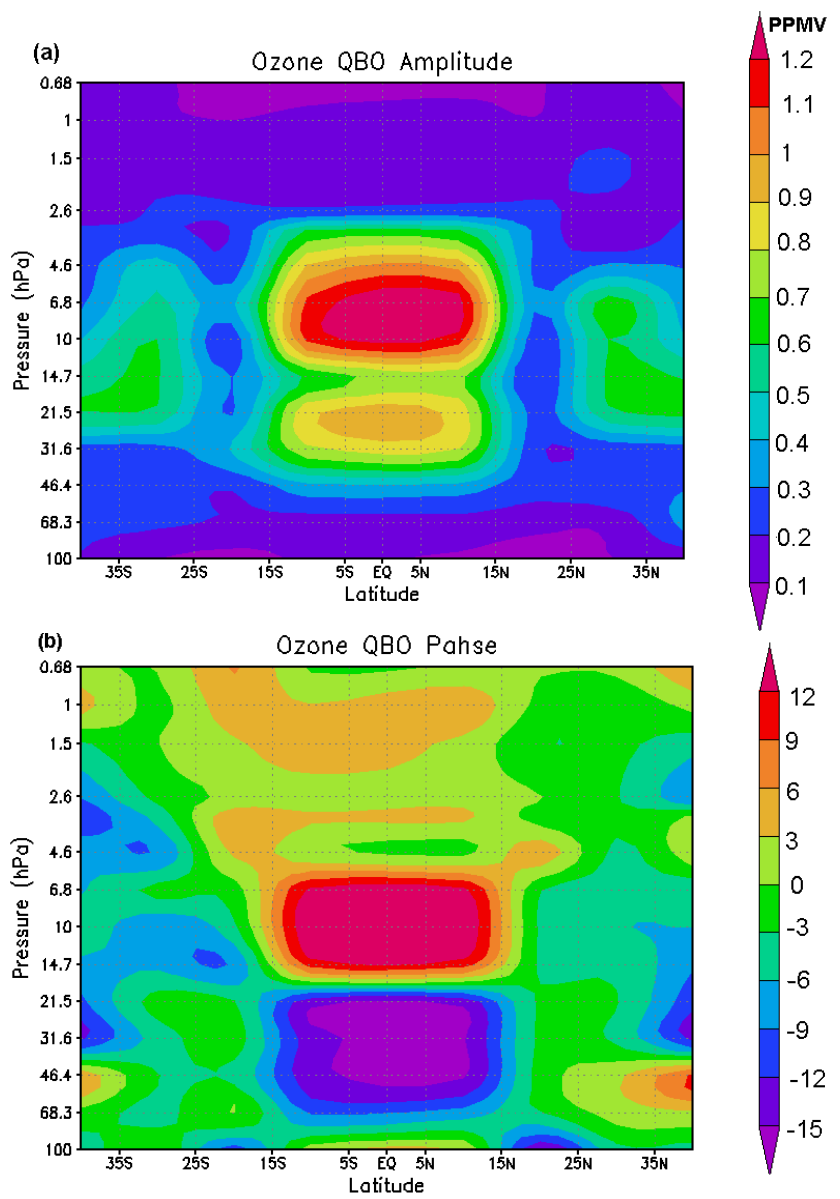

Fig. 7. Latitude-height structure of ozone QBO (a) Amplitude (b) Phase.

to divergence motion. They observed that largest zonal wind $(10-20 \mathrm{~m} / \mathrm{s})$ are associated with zones of meridional divergence only at levels from 10 to $30 \mathrm{hPa}$ (Chio et al., 2002; Baldwin et al., 2001). The observed two peaks are also located near 10 and $30 \mathrm{hPa}$ pressure levels. This indicates that the observed double peak structure in ozone is evidence of secondary meridional circulation induced by the QBO.

Figure 7 a also shows subtropical maximum near $22-6 \mathrm{hPa}$ between $25-35^{\circ} \mathrm{N}-\mathrm{S}$ belts. It is quite evident from Fig. $7 \mathrm{~b}$ that a subtropical peak located between 22 and $6 \mathrm{hPa}$ is of opposite sign to that of equatorial maximum $(\sim 10 \mathrm{hPa})$. Subtropical peak is also observed in SAGE II data (Zawodny and McCormick, 1991; Randel and Wu, 1996). Amplitudes were half of those at the equator, which agrees well with our results. Model simulations by Jones et al. (1998) showed that the QBO induces a meridional circulation which modulates transport of long lived tracers out of tropics. The induced circulation also produces the ozone QBO in subtropics by advection of ozone out of tropics and down from higher altitudes. Baldwin et al. (2001) reported that sub tropical QBO

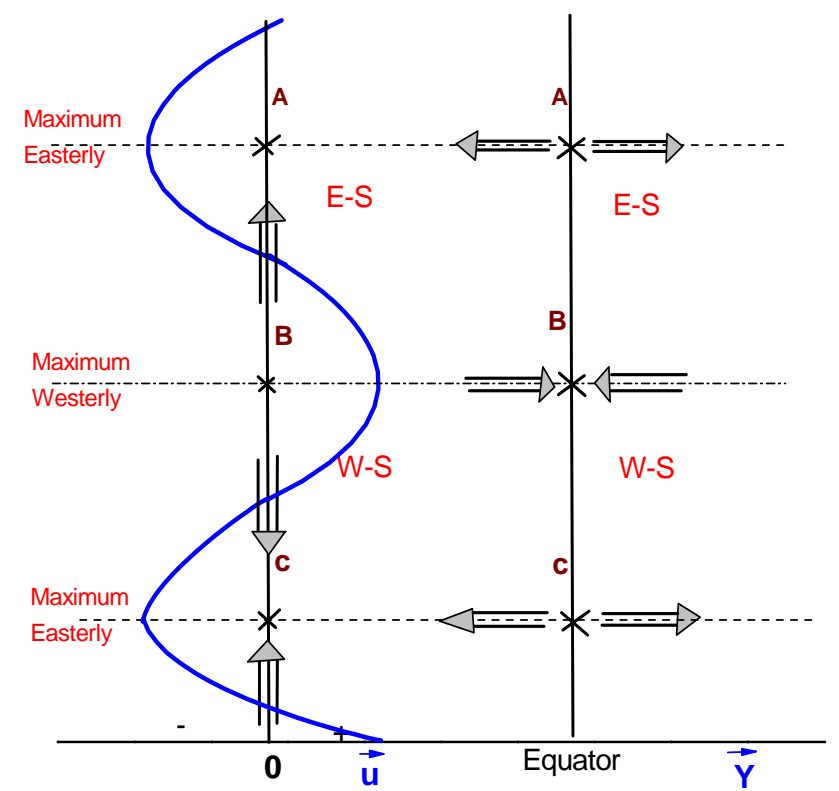

Fig. 8. Schematic vertical profiles of zonal winds, meridional divergence/convergence (reconstructed from Choi et al., 2002).

occurs with the presence of a return arm of the equatorial QBO circulation. Its ascent in the subtropics is associated with westerly equatorial shear. The subtropical anomalies in Fig. $7 \mathrm{a}$ are at lower altitude than that of equatorial positive maximum which is in agreement with Jones et al. (1998). In the present study subtropical anomalies in ozone are centered at about $30^{\circ}$. These results are in agreement with $\mathrm{Za}-$ wodny and McCormick (1991). However, Jones et al. (1998) estimated the center of subtropical anomalies at about $20^{\circ}$ and Tung and Yang (1994) at about $25^{\circ}$. Zawodny and McCormick (1991), Randel and Wu (1996), Gray and Dunkerton (1990), Jones et al. (1998), and Yuejuan et al. (2002) observed a subtropical maximum centered near $20-25^{\circ}$ latitude.

\section{Conclusions}

In this paper spatiotemporal variations of the equatorial quasibiennial oscillation (QBO) in ozone are examined in detail using wavelet analysis. The analysis confirms that the amplitude of the ozone QBO shows evidence of secondary meridional circulation as a double peak structure in the latitudealtitude cross-section of the ozone QBO. The maximum amplitudes ( $>1.4 \mathrm{ppmv}$ ) observed near $22 \mathrm{hPa}$ and $9 \mathrm{hPa}$ are out of phase with each other. This technique has reproduced some of the basic aspects of the QBO, hence it is suitable for QBO analysis, and can be used to study further details.

Height-time structure of the ozone QBO over different tropical and subtropical latitudinal belts, obtained from wavelet analyses, provides minute details of ozone QBO with greater confidence. Present analysis reveals that, in 
the equatorial upper stratosphere the $\mathrm{QBO}$ in winds lags the ozone QBO by up to a quarter cycle and they are out of phase. They are in phase with zero lag in lower and middle stratosphere. Near the stratopause, the subtropical ozone QBO lags (2-6 months) the equatorial QBO. The lag correlation of the subtropical ozone QBO with equatorial ozone QBO does not show a definite relationship in the lower and middle stratosphere. The tropical and subtropical ozone QBO show the zero phase lag with equatorial ozone QBO at the pressure levels (14.7 and $4.6 \mathrm{hPa}$ ) near zero wind levels. The descent rate of easterly phase is greater than westerly. The descent of the ozone QBO is slower in the Southern Hemisphere than the Northern Hemisphere. In the equatorial upper stratosphere ozone anomalies descend with the rate $\sim 1.5 \mathrm{~km} /$ month but in tropics and subtropics (above $2 \mathrm{hPa}$ ) they propagate upward. This may be due to upward transport of ozone out of tropics into subtropics by seasonally varying secondary meridional circulation induced by QBO. Since present results pertain to 4 QBO cycles during 1992 1999 they may be verified using longer data sets.

Acknowledgements. We are thankful to Director IITM for his encouragement during the course of this study. We thank two anonymous reviewers for their valuable suggestions.

Topical Editor U.-P. Hoppe thanks two anonymous referees for their help in evaluating this paper.

\section{References}

Angell, J .K.: Relation of Antartic $100 \mathrm{mb}$ temperature and total ozone to equatorial QBO, equatorial SST and sunspot number 1958-87, Geophys Res Lett., 15, 915-918, 1988.

Baldwin, M. P., Gray, L. J., Dunkerton, T. J., Hamilton, K., Haynes, P. H., Randel, W. J., Holton, J. R., Alexander, M. J.,Hirota, I., Horinouchi, T., Jones, D. B. A., Kennersley, J. S., Marquardt, C., Sato, K., and Takahashi, M.: The quasi-biennial oscillation, Rev. Geophys., 39, 179-229, 2001.

Baliunas, S., Frick, P., Sokoloff, D., and Soon, W.: Time scales and trends in the central England temperature data (1659-1990): A wavelet analysis, Geophys. Res. Lett., 24, 1351-1354, 1997.

Camp, C. D., Roulston, M. S., and Yung, Y. L.: Temporal and spatial patterns of the interannual variability of total ozone in the tropics, J. Geophys. Res., 108(D20), 4643, doi:10.1029/2001JD001504, 2003.

Chandra, S. and McPeters, R. D.: The solar cycle variation od ozone in the stratosphere inferred from Nimbus 7 and NOAA 11 satellites, J. Geophys. Res., 99, 20 665-20 671, 1994.

Choi, W., Lee, H., Grant, W., Park, J. H., Holton, J. R., Lee, W. M., and Naujokat B.: In the secondary meridional circulation associated with the quasi-biennial oscillation, Tellus, 54B, 395406, 2002

Chipperfield, M. P., Gray, L. J., Kinnersley, J. S., and Zawodny, J.: A two-dimensional model study of the QBO signal in SAGE II $\mathrm{NO}_{2}$ and $\mathrm{O}_{3}$, Geophys. Res. Lett., 21, 589-592, 1994.

Cordero, E. C. and Nathan, T. R.: A new pathway for communicationg the 11 year solar cycle signal to the QBO, Geophys. Res. Lett., 32, L18805, doi:10.1029/2005GL023696, 2005.
Dunkerton, T. J.: A two-dimensional model of the quasi-biennial oscillation, J. Atmos. Sci., 42, 1151-1160, 1985.

Dunkerton, T. J.: Quasi-biennial and subbiennial variation of stratospheric trace constituents derived from HALOE observations, J. Atmos. Sci., 58, 7-25, 2001.

Fadnavis, S., Beig, G., and Polade, S. D.: Features of ozone quasi-biennial oscillation in the vertical structure of tropics and subtropics, Meteorol. Atmos. Phys., 99, 221-231, doi:10.1007/s00703-007-0270-7, 2007.

Fadnavis, S. and. Beig, G.: Decadal solar effects on temperature and ozone in the tropical stratosphere, Ann. Geophys., 24, 20912103, 2006, http://www.ann-geophys.net/24/2091/2006/.

Echer, E.,. Guarnieri, F. L., Rigozo, N. R., and Vieira, L. E. A.: A study of the latitudinal dependence of the quasi-biennial oscillation in Total Ozone Mapping Spectrometer total ozone, Tellus A, 56, 527-535, 2004

Fleming, E. L., Jackman, C. H , Rosenfield, J. E., and Considine, D. B.: Two dimensional model simulations of the QBO in ozone and tracers in the tropical stratosphere, J. Geophys. Res., 107(D23), 4665, doi:10.1029/2001JD001146, 2002.

Funk, J. P. and Garnham, G. L.: Australian ozone observations and a suggested 24 month cycle, Tellus, 14, 378-382, 1962.

Gray, L. J. and Dunkerton, T. J.: The role of seasonal cycle in the Quasi-Biennial Oscillation of ozone, J. Atmos. Sci., 47, 24292451, 1990.

Hasebe, F.: Quasi-biennial oscillation of ozone and diabatic circulation in the equatorial stratosphere, J. Atmos. Sci., 51, 729-745, 1994.

Holton, J. R.: The quasi-biennial oscillations in the earth's atmosphere and it's link to longer period variability, NATO ASI Series, I 25, 259-273, 1994.

Holton, J. R.: Influence of annual cycle in meridional transport on the Quasi-Biennial Oscillation in total ozone, J. Atmos. Sci., 46, 1434-1439, 1989.

Jones, D. B. A., Schneider, H. R., and McElroy, M. B.: Effects of the quasi-biennial oscillation on the zonally averaged tranport of tracers, J. Geophys. Res., 103, 11 235-11 249, 1998.

Karol, I. L., Klyagina, L. P., and Shalamyansky, A. M.: Evaluations of seasonal trends of total ozone in a main air masses of Northern Hemisphsere in 1975-86 (21 cycle of solar activity), in: Investigation of atmospheric ozone (Ozone-90), Moskva, Gidrometeoizdat, 1992 (in Russian).

Kinnersley, J. S. and Tung, K. K.: Modeling the global inert-annual variability of ozone due to the equatorial QBO and to extratropical planetary wave variability, J. Geophys. Res., 94, 11 559$11571,1998$.

Kondratiyev, K. Y.: Global dynamics of ozone, in Trudy VINITI, Geomagnetizm high layers of atmosphere, Moskva, 11, p. 210, 1990.

Li, X., Read, P. L., and Andrews, D. G.: Mode selection, wave breaking and parametric sensitivity in the quasi-biennial oscillation, Q. J. Roy. Meteorol. Soc., 123, 2041-2068, 1997.

Lee, H. and Smith, A.: Simulation of the combined effects of solar cycle, QBO, and volcanic forcing on stratospheric ozone changes in recent decades, J. Geophys. Res., 108(D2), 4049, doi:10.1029/2001JD001503, 2003.

Logan, J. A., Jones, D. B., Megretskaia, I. A., Oltmans, S. J., Johnson, B. J., Vomel, H., Randel, W. J., Kimani, W., and Schmidlin, 
F. J.: Quasibiennial oscillation in tropical ozone as revealed by ozonesonde and satellite data, J. Geophys. Res., 108(D8), 4244, doi:10.1029/2002JD002170, 2003.

Mayr, H. G., Mengel, J. G., Drob, D. P., Chan, K. L., and Poryer, H. S.: Modeling studies with QBO: II Solar cycle effect, J. Atmos. Terr. Phys., 65, 901-916, 2003.

McCormack, J. P., Siskind, D. E., and Hood, L. L.: Solar-QBO interaction and its impact on stratospheric ozone in a zonally averaged photochemical transport model of the middle atmosphere, J. Geophys Res., 112, D16109, doi:10.1029/2006JD008369, 2007.

McCormack, J. P.: The influence of the 11 year solar cycle on the quasi-biennial oscillation, Geophys. Res. Lett., 30, 2162, doi:10.1029/2003GL018314, 2003.

Plumb, R. A. and Bell, R. C.: A model of the quasi-biennial oscillation on equatorial beta plane, Q. J. Roy. Meteorol. Soc., 108, 335-352, 1982.

Politowicz, P. A. and Hitchman, M. H.: Exploring the effects of forcing quasi-biennial oscillations in a two dimensional model, J. Geophys. Res., 102, 16 481-16 497, 1997.

Ramanathan, K. R.: Bi-annual variation of atmospheric ozone over the tropics, Q. J. Roy. Meteorol. Soc., 89, 540-542, 1963.

Randel, W. J. and Cobb, J. B.: Coherent variations of monthly mean total ozone and lower stratospheric temperature, J. Geophys. Res., 99, 5433-5477, 1994.

Randel, W. J. and Wu, F.: A stratospheric ozone profile data set for 1979-2005: Variability, trends, and comparisons with column ozone data, J. Geophys. Res., 112, D06313, doi:10.1029/2006JD007339, 2007.

Randel, W. J. and Wu, F.: Isolation of the ozone QBO in SAGE II data by singular decomposition, J. Atmos. Sci., 53, 2546-2559, 1996.

Randel, W. J., Wu, F., Swinbank, R., Nash, J., and O'Neill, A.: Global QBO circulation derived from UKMO stratospheric analysis, J. Atmos. Sci., 56, 457-473,1999.

Ray, E. A. and Holton, J. R.,: The Tropical semiannual oscillation in temperature and ozone as observed by the MLS, J. Atmos. Sci., 50, 3045-3052, 1994.

Reed, R. J., Campbell, W. J., Rasmussen, L. A., and Rogers, R. G.: Evidence and of a downward propagating annual wind reversal in the equatorial stratosphere, J. Geophys. Res., 66, 813-818, 1961.
Riebera, P., Pena-Ortiz, C., Garcia-Harrera, R., Gallego, D., Gimeno, L., and Hernandez, E.: Detection of the secondary meridional circulation associated with Quasi-biennial Oscillation, J. Geophys. Res., 109, D18112, doi:10.1029/2003JD004363, 2004.

Soukharev, B. E.: The interannual variability of temperature in the polar stratosphere during the winter: the influence of the QBO phase and 11 year solar cycle, J. Atmos. Solar-Terr. Phys., 59, 469-477, 1997.

Stolarski, R. S., Bloomfield, P., McPeters, R. D., and Herman, J. R.: Total ozone trends deduced from Nimbus 7 TOMS data, Geophys Res Lett., 18, 1015-1018, 1991.

Thuillier, G. and Bruinsma, S.: The Mg II index for upper atmosphere modeling, Ann. Geophys., 19, 219-228, 2001, http://www.ann-geophys.net/19/219/2001/.

Torrence, C. and Compo, G. P.: A practical guide to wavelet analysis, B. Am. Meteorol. Soc., 70, 61-78, 1998.

Tung, K. and Yang, H.: Global QBO in circulation and ozone, Part II, A simple mechanistic mode, J. Atmos. Sci., 51, 2708-2721, 1994.

Waters, W.: Microwave Limb Sounding, in: Atmospheric Remote Sensing by Microwave Radiometry, edited by: Janssen, M. A., ch. 8, John Wiley, New York, 1993.

Wang, B. and Wang, Y.: Temporal structure of the Southern Oscillation as revealed by waveform and wavelet analysis, J. Climate, 9, 1586-1598, 1996.

Yuejuan, C., Chunhua, S., and Bin, Z.: HCL Quasi-biennial Oscillation in the stratosphere and a comparision with ozone QBO, Adv. Atmos. Sci., 22(5), 751-758, 2005.

Yuejuan, C., Bin, Z., and Zhang, Hong: The features of ozone quasi-biennial oscillation in the tropical stratosphere and its numerical simulation, Adv. Atmos. Sci., 19(5), 777-793, 1995.

Yang, H. and Tung, K. K.: On the phase propagation of extratropical ozone quasi-biennial oscillation in observational data, J. Geophys. Res., 100, 9091-9100, 1995.

Zawodny, J. M. and McCormick, M. P.: Stratospheric Aerorol and GAS Experiment II measurements of the quasi-biennial oscillations in ozone and nitrogen dioxide, J. Geophys. Res., 96, 93719377, 1991. 